\title{
Obituary
}

\section{A Monument to Natural History - Henry S. Fitch (1909-2009)}

\section{William E. Duellman}

Biodiversity Institute, University of Kansas, 1345 Jayhawk Blvd., Lawrence, Kansas 66045, USA. E-mail: duellman@ku.edu.

A lengthy era of herpetological natural history ended on September 8, 2009, when Henry S. Fitch died, just a few weeks before his $100^{\text {th }}$ birthday (December 25). Considered by many of his colleagues and students as the father of snake ecology, Henry Fitch (Figure 1) greatly expanded our knowledge of the life histories of amphibians and reptiles, especially snakes, through his many detailed publications spanning seven decades.

After completing his undergraduate education at the University of Oregon, Fitch was accepted for graduate work under the tutelage of the master naturalist Joseph Grinnell at the University of California at Berkeley. Between the time of receiving his $\mathrm{PhD}$ in 1937 and joining the faculty at the University of Kansas in 1948, Fitch was employed as a biologist in California and in Louisiana; he was drafted in 1941 and spent nearly five years in the United States Army. However, during this interval he published several important papers on the systematics of anguid lizards of the genus Gerrhonotus (now Elgaria) and colubrid snakes of the genus Thamnophis (Fitch 1938, 1940, 1941).

In 1948, the University of Kansas designated a tract of land just a few kilometers outside of Lawrence to be a Natural History Reservation. Henry S. Fitch was hired as an assistant professor in the Department of Zoology and as superintendent of the reservation. Thus began his intensive studies of the inhabitants of this one square mile $\left(2.6 \mathrm{~km}^{2}\right)$

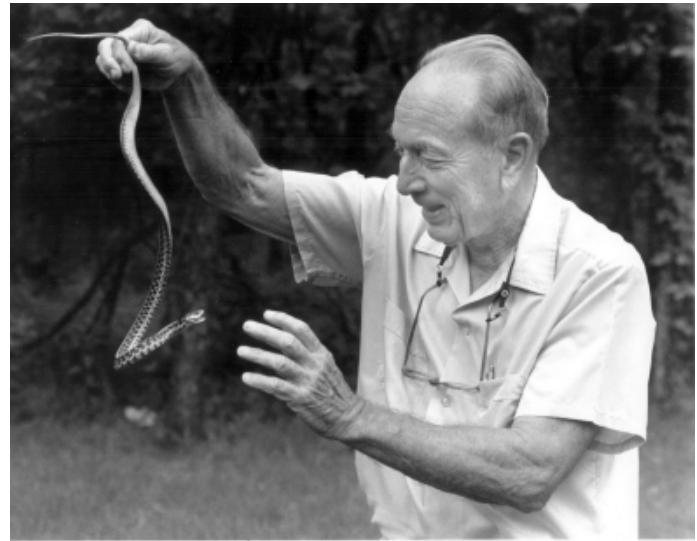

Figure 1 - Henry S. Fitch with a Thamnophis sirtalis at the Fitch Natural History Reservation, 23 May 1991. Photograph by Vada Snider.

of deciduous hardwood forest in northeastern Kansas. He and his family lived in a small house on the reservation. His wife, Virginia, helped him in many ways, as did his three children, one of whom, Alice, subsequently collaborated with him on several publications.

It was on this small section of land that Henry Fitch reached the height of his achievements. Early in this part of his career he determined the kinds of data necessary for ecological studies of life histories of reptiles (Fitch 1949). As emphasized by Greene (2009), MacArthur and Pianka's (1966) conceptual paper on optimal use of the environment would inspire widespread measurement of parameters that Fitch had been recording for decades with 
no conceptual prompting. Fitch experimented with various kinds of traps for capturing, but not harming, small mammals and reptiles and provided details of their construction (Fitch 1950, 1951); subsequent generations of ecologists have put them to use. These traps and artificial cover (and later telemetry) were essential parts of his ability to capture, mark, and recapture individual animals, thereby providing the data essential for autecological studies to determine relationships of those species with their physical environment and with their plant and animal associates. Fitch (1958a) emphasized: "In order to understand the ecology of a species it is necessary to recognize individuals and to trace individual histories. It is necessary to ascertain how the typical individual animal is limited in time and space in order to understand the population dynamics of the species."

Fitch only published one study on amphibians, the microhylid frog Gastrophryne olivacea, of which 1215 individuals led to 1472 recaptures over a period of six years (Fitch 1956a). He published four classic papers on the life histories and ecology of lizards, e.g., Eumeces (= Plestiodon) fasciatus, Crotaphytus collaris, Cnemidophorus (= Aspidoscelis), and Ophisaurus attenuatus (Fitch 1954, 1956b, 1958b, 1989). The numbers of records and recaptures of some of the species are nearly astronomical. For example, he recorded one individual of Crotaphyus collaris 101 times during six years; 230 individuals of Aspidoscelis sexlineatus were recaptured 581 times during 14 years, and 2116 individuals of Ophisaurus ventralis were captured 3353 times over a period of 35 years.

However, Fitch's forte was snakes. Three studies are classics in autecology - Copperhead (Agkistrodon contortrix), Common Racer (Coluber constrictor), and Ring-neck Snake (Diadophis punctatus) (Fitch 1960, 1963, 1975a). Again the numbers of individuals meticulously recorded for place and date of capture, length, weight, food, sex, and gravidity of females is astonishing autecology - 1532 Agkistrodon, 1020 Coluber, and more than 14,000 Diadophis). Fitch (1993) summarized relative abundances of Kansas snakes, wherein he noted that his results were based on data on 33,117 snakes of 34 species. In 1999, his grand summary of the field study for 50 consecutive years on 18 species of snakes was advertised as the longest running single-site study of vertebrates ever done (Fitch 1999). Almost as an after thought, Fitch (2000) published on the population structure and biomass of local populations of snakes with samples of 113 to 1762 individuals of each of 11 species. Therein he documented 18 age cohorts in Crotalus atrox and noted that the diminutive Diadophis punctatus made up about one half of the total biomass. Nearly all of the data in these studies came from animals on that one square mile of land in northeastern Kansas, which in 1986 became appropriately named The Fitch Natural History Reservation.

Fitch's publications contained all appropriate references to the taxon under consideration. He built up a tremendous index to publications on the life histories of squamates (without the aid of computer programs). By integrating the extensive literature and his own observations on living and preserved lizards and snakes he produced four major syntheses on reproductive cycles, sexual size differences, and clutch and litter size (Fitch 1970, 1981, 1982, 1985).

In 1967, I introduced Henry Fitch to the Amazon rainforest at Santa Cecilia, Ecuador. During the month that we spent in a small "campamento," I was amazed that this man, 20 years my senior, had such stamina and endurance in the humid tropics, apparently equal to that witnessed by many of his beleaguered students in temperate North America. Henry seemed to get an "itch" for the tropics, because soon after that he initiated ecological studies on lizards, principally Anolis, in Mexico and Central America (e.g., Fitch 1972, 1973, 1975b; Fitch and Henderson 1975). 


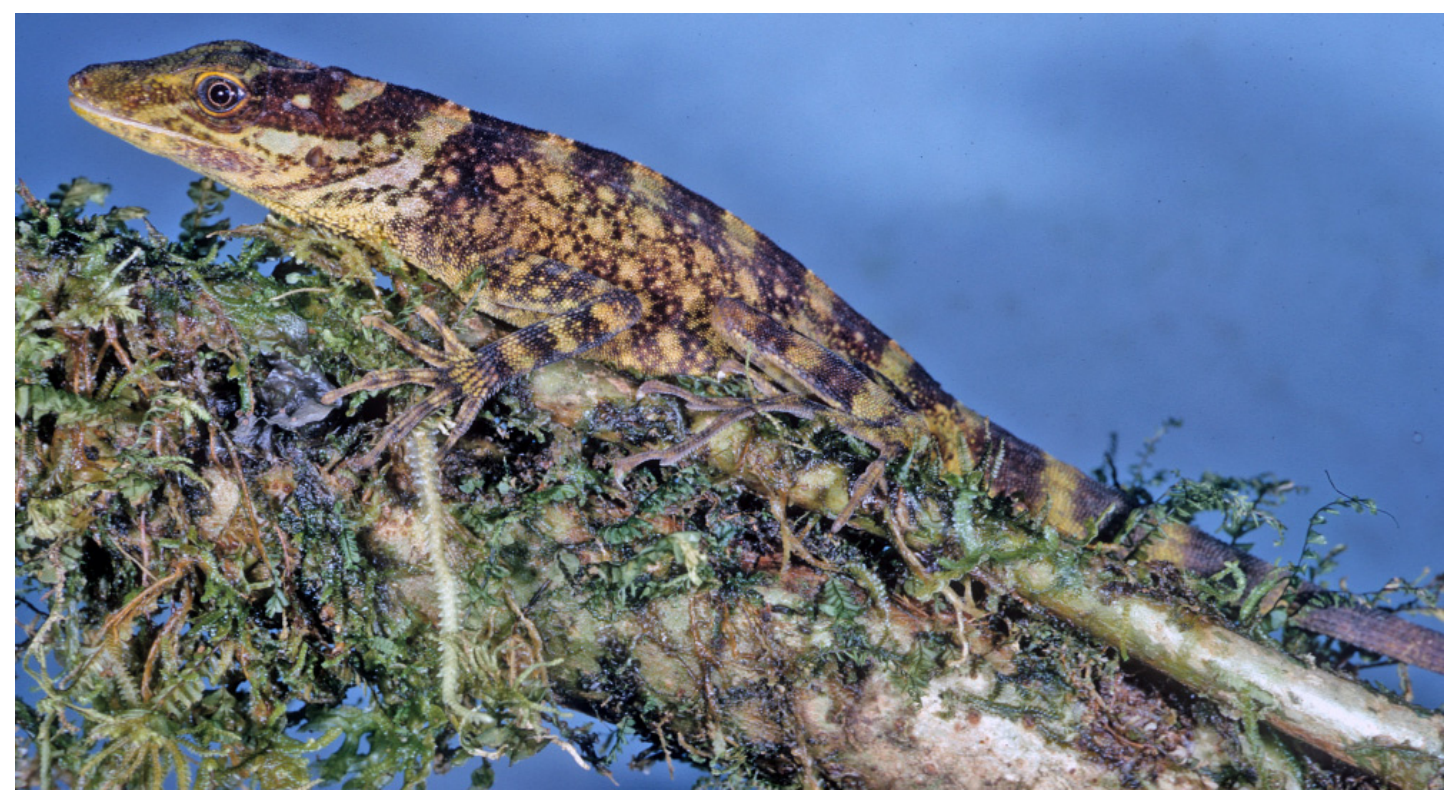

Figure 2 - Holotype of Anolis fitchi, KU 142865, 16.5 km NNE Santa Rosa, Provincia Napo. Ecuador. Photograph by William E. Duellman.

Soon after he began working on Anolis in the American tropics, he encountered taxonomic problems. Thus, characteristic of his thoroughness, he undertook necessary systematic studies (e.g., Fitch et al. 1972; Fitch and Henderson 1973). Later Fitch studied the ecology of anoles in the West Indies (e.g., Fitch et al. 1989, Fitch and Henderson 1987). During his work on Anolis, Fitch undertook investigations of the relationships between dewlap morphology and habitat (Fitch and Hillis 1984). Such diversions were typical of Fitch's broad interests in natural history. Although he is best known for his contributions to our knowledge of the life histories and ecology of reptiles, he also published extensively on birds, mammals, and even spiders.

In August 1980, a symposium entitled "Perspectives in Fitchian Ecology" was held in conjunction with the meetings of the Society for the Study of Amphibians and Reptiles and the Herpetologists' League in Milwaukee
Wisconsin, USA; this symposium honored Henry Fitch on the occasion of his retirement. Here it should be noted that he continued active field studies for an additional 26 years. The results of the symposium were published (Seigel et al. 1984). I was honored to provide an introduction (Duellman 1984), in which I stated: "At the present time, many biologists are narrow specialists. Henry Fitch does not fit into a modern pigeon hole. He is a naturalist in the broadest sense of the word. His breadth of knowledge is matched by very few of his contemporaries and scarcely imagined by most of his younger colleagues. An analogy can be drawn with the story of the hare and the tortoise. With Henry Fitch as the tortoise steadily plodding along his path of scientific endeavor, frequently being passed by various biological bandwagons, only to find them sometimes morassed or abandoned further down the road." In the same volume Williams and Duellman (1984) honored Henry Fitch by naming Anolis fitchi (Figure 2). 
NOTE: For a lengthy summary of Henry Fitch's life, see Echelle and Stewart (2000), and for various perspectives on Fitch as a scientist and person, see Greene et al. (2009). All of Fitch's papers published by the University of Kansas are incorporated in the Biodiversity Heritage Library, where they can be downloaded at www.biodiversitylibrary.org.

\section{References}

Duellman, W. E. 1984. Henry S. Fitch in perspective. P. 3 in R. A. Seigel, L. E. Hunt, J. L. Knight, L. Malaret, and N. L. Zuschlag (eds.), Vertebrate ecology and systematics: A tribute to Henry S. Fitch. Special Publication University of Kansas Museum of Natural History 10: 1-278.

Echelle, A. F. and M. M. Stewart. 2000. Historical perspective: Henry S. Fitch. Copeia 2000: 891-900.

Fitch, H. S. 1938. A systematic account of the alligator lizards (Gerrhonotus) in the western United States and Lower California. American Midland Naturalist 20: $381-424$.

Fitch, H. S. 1940. A biogeographical study of the ordinoides artenkreis of garter snakes (genus Thamnophis). University of California Publications, Zoology 44: 1-150.

Fitch, H. S. 1941. Geographic variation in garter snakes of the species Thamnophis sirtalis in the Pacific coast region of North America. American Midland Naturalist 26: $570-572$.

Fitch, H. S. 1949. Outline for ecological life history studies of reptiles. Ecology 30: 520-532.

Fitch, H. S. 1950. A new style live-trap for small mammals. Journal of Mammalogy, 31: 364-365.

Fitch, H. S. 1951. A simplified type of funnel trap for reptiles. Herpetologica 7: 77-80.

Fitch, H. S. 1954. Life history and ecology of the five-lined skink. Eumeces fasciatus. University of Kansas Publications, Museum of Natural History 8: 1-156.

Fitch, H. S. 1956a. A field study of the Kansas ant-eating frog, Gastrophryne olivacea. University of Kansas Publications, Museum of Natural History 8: 275-306.

Fitch, H. S. 1956b. An ecological study of the collared lizard (Crotaphytus collaris). University of Kansas Publications, Museum of Natural History 8: 213-274.

Fitch, H. S. 1958a. Home ranges, territories, and seasonal movements in vertebrates of the Natural History Reservation. University of Kansas Publications, Museum of Natural History 11: 63-326.
Fitch, H. S. 1958b. Natural history of the six-lined racerunner (Cnemidophorus sexlineatus). University of Kansas Publications, Museum of Natural History 11: 11-62.

Fitch, H. S. 1960. Autecology of the copperhead. University of Kansas Publications, Museum of Natural History 13: 85-288.

Fitch, H. S. 1963. Natural history of the racer, Coluber constrictor. University of Kansas Publications, Museum of Natural History 15: 351-468.

Fitch, H. S. 1970. Reproductive cycles in lizards and snakes. Miscellaneous Publication, Museum of Natural History, University of Kansas 52: 1-247.

Fitch, H. S. 1972. Ecology of Anolis tropidonotus in Costa Rican cloud forest. Herpetologica 28: 10-21.

Fitch, H. S. 1973. Observations on the population ecology of the Central American iguanid lizard, Anolis cupreus. Caribbean Journal of Science 13: 215-229.

Fitch, H. S. 1975a. A demographic study of the Ring-neck snake (Diadophis punctatus) in Kansas. Miscellaneous Publication, Museum of Natural History, University of Kansas 62: 1-53.

Fitch, H. S. 1975b. Sympatry and interrelationships in Costa Rican anoles. Occasional Papers, Museum of Natural History, University of Kansas 40: 1-60.

Fitch, H. S. 1981. Sexual size differences in reptiles. Miscellaneous Publication, Museum of Natural History, University of Kansas 70: 1-72.

Fitch, H. S. 1982. Reproductive cycles in tropical reptiles. Occasional Papers, Museum of Natural History, University of Kansas 96: 1-53.

Fitch, H. S. 1985. Variation in clutch and litter size in New World reptiles. Miscellaneous Publication, Museum of Natural History, University of Kansas 76: 1-76.

Fitch, H. S. 1989. A field study of the slender glass lizard, Ophisaurus attenuatus, in Kansas. Occasional Papers, Museum of Natural History, University of Kansas 125: $1-50$.

Fitch, H. S. 1993. Relative abundance of snakes in Kansas. Transactions of the Kansas Academy of Science 96: 213-224.

Fitch, H. S. 1999. A Kansas Snake Community: Composition and Changes over 50 Years. Malabar, Florida: Krieger Publishing Company, xi+165 pp.

Fitch, H. S. 2000. Population structure and biomass of some common snakes in Central North America. Scientific Papers Natural History Museum, University of Kansas 17: 1-7.

Fitch, H. S. and R. W. Henderson. 1973. A new anole (Reptilia: Iguanidae) from southern Veracruz, Mexico. Journal of Herpetology 7: 125-128. 
Fitch, H. S. and R. W. Henderson. 1975. A comparative study of the structural and climatic habits of Anolis sericeus (Reptilia: Iguanidae) and its syntopic congeners at four localities in southern Mexico. Herpetologica 32: 459-471.

Fitch, H. S. and R. W. Henderson. 1987. Ecological and ethological parameters in Anolis bahorucoensis, a species having rudimentary development of the dewlap. Amphibia-Reptilia 8: 69-80.

Fitch, H. S. and D. M. Hillis. 1984. The Anolis dewlap: interspecific variability and morphological association with habitat. Copeia 1984: 315-323.

Fitch, H. S., A. A. Echelle and A. F. Echelle. 1972. Variation in the Central American iguanid lizard, Anolis cupreus, with the description of a new subspecies. Occasional Papers, Museum of Natural History, University of Kansas 8: 1-20.

Fitch, H. S., R. W. Henderson and H. Guarisco. 1989. Aspects of the ecology of an introduced anole: Anolis cristatellus in the Dominican Republic. AmphibiaReptilia 10: 307-320.
Greene, H. W. 2009. Henry Fitch and the practice of natural history. Pp. 393-394 in Greene, H. W., W. E. Duellman, M. J. Plummer, R. W. Henderson, D. M. Hillis, R. A. Seigel, R. B. Huey, and G. R. Pisani. 2009. Henry S. Fitch (1909-2009): Field notes on a wonderful life. Herpetological Review 40: 393-400.

MacArthur, R. H. and E. R. Pianka. 1966. On optimal use of a patchy environment. American Naturalist 100: 603-609.

Seigel, R. A., L. E. Hunt, J. L. Knight, L. Malaret, and N. L. Zuschlag (eds.). 1984. Vertebrate ecology and systematics: A tribute to Henry S. Fitch. Special Publication University of Kansas Museum of Natural History 10:1-278.

Williams, E. E. and W. E. Duellman. 1984. Anolis fitchi, a new species of the Anolis aequatorialis group from Ecuador and Colombia. Pp. 257-266 in Seigel, R. A., L. E. Hunt, J. L. Knight, L. Malaret, and N. L. Zuschlag (eds.). 1984. Vertebrate ecology and systematics: A tribute to Henry S. Fitch. Special Publication University of Kansas Museum of Natural History 10:1-278. 